Gut, 1974, 15, 213-219

\title{
The immune competence of patients with inflammatory bowel disease
}

\author{
P. M. BOLTON, SUSAN L. JAMES, R. G. NEWCOMBE, R. H. WhitehEAD, AND \\ L. E. HUGHES
}

From the Departments of Surgery and Medical Statistics, Welsh National School of Medicine, Cardiff

SUMMARY Previous investigations of immune function in patients with Crohn's disease have yielded conflicting results. A comprehensive study of immune competence-peripheral lymphocyte count, serum immunoglobulin levels (IgG, IgA and IgM), lymphocyte response to PHA, Mantoux test, and DNCB response-has been performed in a large number of patients with inflammatory bowel disease. A total of 52 patients with Crohn's disease, 20 patients with ulcerative colitis, and 46 control patients with benign gastrointestinal disease were investigated. The patient groups were subdivided into 'well' and 'ill' in view of the differing clinical states of patients with inflammatory bowel disease. Some of the Crohn's and colitis patients were receiving steroid therapy.

The peripheral blood lymphocyte count and lymphocyte response to PHA were similar in all patient groups. Serum IgA levels were elevated in Crohn's disease but fell significantly in 'ill' Crohn's patients following excisional surgery. Serum IgM levels rose significantly in 'ill' Crohn's patients after surgery. Steroid therapy was associated with diminution of both Mantoux and DNCB responses in the 'ill' Crohn's patients. There was no evidence of impairment of immune competence in either Crohn's disease or ulcerative colitis.

Crohn's disease and ulcerative colitis are disorders of unknown aetiology. Immunological mechanisms have been considered to be of major significance in their aetiology and pathogenesis, but conclusive evidence is lacking. One aspect of immunity, nonspecific immune competence, has been studied by several groups with conflicting results.

In general, studies in ulcerative colitis patients have not revealed a depression of immune competence (Hinz, Perlmann, and Hammarström, 1967; Parent, Barrett, and Wilson, 1971). In contrast, patients with Crohn's disease have shown a high incidence of negative Mantoux responses (Blackburn, Hadfield, and Hunt, 1939; Phear, 1958; Williams, 1965), as well as diminished cutaneous delayed hypersensitivity reactions to dinitrochlorobenzene (Jones, Housley, Ashurst, and Hawkins, 1969). Also the lymphocytes of patients with Crohn's disease have shown low responses to nonspecific mitogens such as phytohaemagglutinin (Walker and Greaves, 1969; Brown, Taub, Present, and Janowitz, 1970; Parent et al, 1971). However,

Received for publication 15 January 1974. other groups have found the lymphocyte response to mitogens to be normal (McHattie, Magil, Jeejeebbhoy, and Falk, 1971; Aas, Huizenga, Newcomer, and Shorter, 1972; Asquith, Kraft, and Rothberg, 1973) and the Mantoux reaction in Crohn's patients to be unimpaired (Fletcher and Hinton, 1967; Geffroy, Colin, Hecketsweiler, and Segrestin, 1971).

There are several possible reasons for these conflicting reports. The clinical status of patients with Crohn's disease fluctuates widely with exacerbations and remissions, and these changes in degree of illness may non-specifically affect immune status. The treatment of some patients with steroids or other anti-inflammatory medication may modify the immune response. Controls for the immunological testing have usually been healthy volunteers rather than patients with a comparable degree of illness. Also, most groups have used a single test of immune competence.

In an effort to resolve these conflicting results, we have performed a spectrum of tests of immune function in each patient, namely, peripheral blood lymphocyte count, serum immunoglobulin levels (IgG, $\operatorname{IgA}$, and $\operatorname{IgM})$, lymphocyte response to 
phytohaemagglutinin (PHA), Mantoux test, and dinitrochlorobenzene (DNCB) response.

Degree of illness was considered the most important factor in the selection of controls, who were patients admitted for investigation of non-malignant gastrointestinal disease. Most subsequently underwent surgery.

\section{Patients and Methods}

\section{PATIENTS}

\section{Crohn's disease patients}

A series of 52 consecutive, unselected patients was studied. The age range was $12-77$ years, with a mean of 36 years. Twenty-five patients were male and 27 female. The diagnosis had been, or was later, confirmed histologically in 42 patients, while the remaining 10 exhibited typical clinical and radiological features. The disease affected the small bowel alone in 16 patients, small bowel and colon in 31 patients, and the colon alone in five cases.

All patients had evidence of active disease, but there was wide variation in their clinical state, allowing subdivision into two groups. Thirty-three of the 52 patients were ill at the time of testing. All but five of these 'ill' patients were inpatients, and many came to subsequent surgery. The disease was relatively quiescent in the remaining 19 patients who were tested at follow-up outpatient clinics. This latter group of patients was considered 'well' at the time of immune competence testing, although minor symptoms, signs, and/or radiological evidence of persistent disease were present.

Treatment was not altered or withheld in relation to the immunological tests. Because of this, at the time of testing 22 of the 33 'ill' patients were receiving systemic steroids at a median dose level of $15 \mathrm{mg}$ prednisone per day. Five of the 19 'well' patients were also receiving systemic steroids, the median dose being $5 \mathrm{mg}$ prednisone per day. The drug treatment of the Crohn's patients is shown in table I.

\begin{tabular}{lllll}
\hline $\begin{array}{l}\text { Degree of } \\
\text { Illness }\end{array}$ & No Drugs & $\begin{array}{l}\text { Systemic } \\
\text { Steroids } \\
\text { Alone }\end{array}$ & $\begin{array}{l}\text { Salazopyrine } \\
\text { Alone }\end{array}$ & $\begin{array}{l}\text { Systemic } \\
\text { Steroids } \\
\text { Plus Other } \\
\text { Drugs }\end{array}$ \\
\hline $\begin{array}{l}\text { Well patients } \\
\text { (19) }\end{array}$ & 12 & $2^{1}$ & 2 & $3^{1,3}$ \\
$\begin{array}{l}\text { III patients } \\
\text { (33) }\end{array}$ & 7 & $10^{2}$ & 4 & $12^{2,4}$ \\
\hline
\end{tabular}

Table I Drug treatment of Crohn's patients

${ }^{1}$ Median dose of prednisone $=5 \mathrm{mg} /$ day ; ${ }^{2}$ median dose of prednisone $=15 \mathrm{mg} / \mathrm{day} ;{ }^{3}$ on z patient each on ACTH, salazopyrine, and azathioprine; 'six patients on salazopyrine, two patients on ACTH and two on azathioprine, one patient on 6-mercaptoprine and one on ACTH, salazopyrine, and azathioprine

\section{Ulcerative colitis patients}

These numbered 20 with an age range of 17 to 78 years, and a mean of 39 years. Eight patients were male and 12 female. The diagnosis was based on subsequent histological examination of the resected colon in five cases and typical clinical and radiological findings in the remaining 15 . In no case was disease confined to the rectum. Thirteen were considered 'ill' at the time of testing, 10 of these being inpatients with acute exacerbations of colitis. The remaining seven were in remission and were regarded as 'well'. None of the seven 'well' patients was on systemic steroids, but seven of the 13 'ill' patients were receiving hydrocortisone, cortisone, or prednisone. The median steroid dose level was equivalent to $30 \mathrm{mg}$ of prednisone per day. The drug therapy of the ulcerative colitis patients is shown in table II.

\begin{tabular}{lllll}
\hline $\begin{array}{l}\text { Degree of } \\
\text { Illness }\end{array}$ & No Drugs & $\begin{array}{l}\text { Systemic } \\
\text { Steroids } \\
\text { Alone }\end{array}$ & $\begin{array}{l}\text { Salazopyrine } \\
\text { Alone }\end{array}$ & $\begin{array}{l}\text { Systemic } \\
\text { Steroids } \\
\text { Plus Other } \\
\text { Drugs }\end{array}$ \\
\hline $\begin{array}{l}\text { Well patients } \\
\text { (7) }\end{array}$ & 1 & 0 & 6 & 0 \\
$\begin{array}{l}\text { Ill patients } \\
\text { (13) }\end{array}$ & 1 & $3^{1}$ & 5 & $4^{1,2}$ \\
\hline
\end{tabular}

Table II Drug treatment of ulcerative colitis patients

${ }^{1}$ Median steroid dose equivalent to $30 \mathrm{mg}$ prednisone per day; 'all four patients also on salazopyrine.

\section{Control patients}

This group comprised 46 patients admitted for investigation and usually surgery for non-malignant gastrointestinal disease. The age range was 23-83 (mean 56 years) and the sex division was 29 male and 17 female. The most frequent diagnoses were peptic ulceration (20 patients), diverticular disease of the colon (six patients), and benign tumours of the bowel (six patients). Thirty-five of this group of 46 patients underwent abdominal surgery.

Judged by the clinical state at the time of testing, 24 were considered 'ill' and 22 'well'. None of these control patients was receiving steroid therapy.

\section{IMMUNOLOGICAL TESTING}

Informed consent was obtained in all cases before testing. Blood samples for lymphocyte count, immunoglobulin levels, and PHA lymphocyte response were taken, and DNCB sensitization was carried out on the same day. DNCB challenge and Mantoux testing were performed 12-14 days later.

Serial testing was carried out on patients who underwent surgery or whose clinical state changed significantly. 


\section{Lymphocyte count}

An automatic counter recorded total white cell count. Lymphocyte count per cubic millimetre was calculated after examination of 200 leucocytes on a stained film.

\section{Serum immunoglobulin levels}

IgG, IgA, and IgM levels were measured by the radial immunodiffusion technique of Mancini, Carbonara, and Heremans (1965) using Behringwerke AG Tri-Partigen plates, and allowing the diffusion to go to completion. Comparability of results over the period of the investigation was ensured by testing, with each set of determinations, a portion of a pool of normal serum, stored at about $-20^{\circ} \mathrm{C}$. The results obtained for the pool did not vary significantly.

\section{Lymphocyte response to $\mathrm{PHA}$}

Leucocytes from $15 \mathrm{ml}$ of venous blood (250 iu preservative-free heparin) were separated by the method of Coulson and Chalmers (1964). The leucocytes were suspended at a concentration of $5 \times 10^{5}$ per $\mathrm{ml}$ in TCM 199 with $20 \%$ foetal bovine serum with Hepes buffer $(15 \mathrm{mM}), 1.5 \mathrm{ml}$ cultures containing $7.5 \times 10^{5}$ cells, and $3 \mu \mathrm{g}$ purified PHA (Wellcome) were set up in quadruplicate in screwcapped tubes. Control cultures without PHA were similarly performed in quadruplicate. The cultures were incubated in $5 \% \mathrm{CO}_{2}$ at $37^{\circ} \mathrm{C}$ for 70 hours before labelling with $3 \mu \mathrm{C}$ of tritiated thymidine (specific activity $18.5 \mathrm{c} / \mathrm{mMol}$ ) for one hour. Cells were washed into centrifuge tubes with ice-cold saline, re-washed twice, treated with cold $5 \%$ trichloracetic acid and then with $5 \mathrm{ml}$ methanol. Pellets were allowed to dry overnight, digested with $0.2 \mathrm{ml}$ Protosol (New England Nuclear) and taken up in $10 \mathrm{ml}$ scintillation fluid $(5 \mathrm{~g}$ PPO, $0.1 \mathrm{~g}$ dimethyl POPOP, and 1 litre toluene). After equilibration, samples were counted in an LKB-Wallac scintillation counter. Results were expressed as counts per minute in stimulated cultures minus counts per minute in unstimulated cultures per $10^{6}$ cells. Each result represented the mean of quadruplicate cultures.

\section{Mantoux test}

$0 \cdot 1 \mathrm{ml}$ of $1: 1000$ purified protein derivative (PPD), equivalent to 10 units of Old Tuberculin, was injected intradermally unless there was a history of tuberculosis or close contact, when $0.1 \mathrm{ml}$ of 1:10 000 PPD was used initially in case of excessive reaction. The diameter of the induration was measured at $\mathbf{7 2}$ hours. Induration of $4 \mathrm{~mm}$ or more constituted a positive response.

\section{$D N C B$ response}

The DNCB sensitization and challenge were performed essentially as described by Aisenberg. (1962) but using a lower sensitizing dose. In brief, $2000 \mu \mathrm{g}$ DNCB in $0.1 \mathrm{ml}$ acetone was applied within a plastic ring of $2.2 \mathrm{~cm}$ diameter to the front of the upper arm. At the same time $100 \mu \mathrm{g}$ DNCB in $0.1 \mathrm{ml}$ acetone was applied similarly to the volar surface of the forearm to detect prior sensitization. These sites were allowed to dry and were occluded by a dressing for 48 hours. Challenge doses of $50 \mu \mathrm{g}$ and $100 \mu \mathrm{g}$ DNCB were applied to the forearm 12-14 days later and the sites occluded for 24 hours. Responses were read at 72 hours, a positive response comprising induration and erythema at the test site.

\section{STATISTICAL METHODS}

Analysis of lymphocyte counts and immunoglobulin levels was carried out using $t$ tests. Lymphocyte responses to PHA were assessed using $t$ tests on log values. The Mantoux responses were evaluated by $t$ tests on grades of response and Mann-Whitney tests to corroborate these. DNCB reactions were analysed using the Mann-Whitney test.

\section{Results}

\section{INITIAL TESTS}

\section{Lymphocyte count}

There was no significant variation between Crohn's disease, colitis, and control patients overall or in relation to degree of illness or steroid therapy. Mean lymphocyte counts of the patient groups are shown in table III.

\section{Serum immunoglobulin levels (table III)}

No overall differences in IgG levels were found between Crohn's disease, colitis, and control patients. However, IgG levels in steroid-treated 'well' Crohn's disease patients were significantly lower than in non-steroid treated 'well' Crohn's patients $(\mathrm{P}<0.02)$ and also lower than in steroidtreated 'ill' Crohn's patients $(P<0.02)$.

Comparing the groups as a whole, $\operatorname{IgA}$ levels were significantly greater in Crohn's disease patients than in colitis patients $(P<0.005)$ or controls $(P<0.05)$. Values in colitis and control groups were not significantly different.

Among 'ill' patients of both steroid- and nonsteroid-treated groups, serum IgA levels were significantly higher in Crohn's disease than in ulcerative colitis $(P<0.02)$ but this difference was not seen in the 'well' groups of patients.

In steroid-treated Crohn's patients, IgA levels were very significantly higher in the 'ill' than in the 


\begin{tabular}{|c|c|c|c|c|c|c|}
\hline Patient Group & Degree of Illness & Steroid Therapy & $\begin{array}{l}\text { Lymphocyte Count } \\
\left(\times 10^{3} / \mathrm{cmm}\right)\end{array}$ & $\begin{array}{l}\operatorname{IgG} \\
(\mathrm{mg} / 100 \mathrm{ml})\end{array}$ & $\begin{array}{l}\operatorname{lgA} \\
(\mathrm{mg} / 100 \mathrm{ml})\end{array}$ & $\begin{array}{l}I g M \\
(\mathrm{mg} / 100 \mathrm{ml})\end{array}$ \\
\hline \multirow{6}{*}{$\begin{array}{l}\text { Crohn's disease } \\
\text { (52) }\end{array}$} & \multirow{3}{*}{$\begin{array}{l}\text { Well } \\
\text { (19) }\end{array}$} & $t^{1}$ & & & & \\
\hline & & (5) & $2 \cdot 78$ & $882^{4,8}$ & $134^{7,8}$ & 101 \\
\hline & & (14) & $2 \cdot 20$ & $1221^{4}$ & $291^{\circ}$ & 129 \\
\hline & \multirow{3}{*}{ IIl } & $\begin{array}{l}+8 \\
(22)\end{array}$ & 1.87 & $1323^{5}$ & $377^{\circ, 7}$ & 152 \\
\hline & & - & & & & \\
\hline & & (11) & 1.93 & 1180 & $310^{\circ}$ & 137 \\
\hline \multirow{5}{*}{$\begin{array}{l}\text { Colitis } \\
\text { (20) }\end{array}$} & Well & - & & & & \\
\hline & (7) & (7) & $2 \cdot 32$ & 1357 & 222 & 155 \\
\hline & \multirow{3}{*}{$\begin{array}{l}\text { III } \\
\text { (13) }\end{array}$} & +8 & & & & \\
\hline & & (7) & 1.63 & 1183 & $241^{\circ}$ & 170 \\
\hline & & (6) & 2.54 & 1319 & $168^{\circ}$ & 128 \\
\hline \multirow{3}{*}{$\begin{array}{l}\text { Controls } \\
\text { (46) }\end{array}$} & Well & - & & & & \\
\hline & (22) & (22) & $2 \cdot 33$ & 1199 & 217 & 125 \\
\hline & III & $\overline{(24)}$ & $2 \cdot 26$ & 1153 & 252 & 114 \\
\hline
\end{tabular}

Table III Mean lymphocyte counts and serum immunoglobulin levels

${ }^{1}$ Median dose of prednisone $=5 \mathrm{mg} / \mathrm{day} ;{ }^{2}$ median dose of prednisone $=15 \mathrm{mg} /$ day; ${ }^{3}$ median steroid dose equivalent to $30 \mathrm{mg}$ prednisone $/$ day $4,5,{ }_{P}<0.02 ;{ }^{7} P<0.001 ;{ }^{8} \mathbf{P}<0.006$

'well' ( $\mathrm{P}<0.001)$. In both Crohn's and colitis patients not on steroids, the degree of illness had no effect on IgA levels.

Steroids were associated with depression of serum IgA in 'well' Crohn's disease patients $(P<0.006)$ but did not have any significant effect on IgA leves in such 'ill' patients or in the 'ill' colitis patients.

Serum IgM levels were not significantly different in the three major groups of patients. Values in the 'ill' Crohn's disease and 'ill' colitis patients were greater than in 'ill' control patients, but these differences just failed to attain statistical significance.

\section{Lymphocyte response to $\mathrm{PHA}$}

There was a wide variation within patient groups, but no significant difference related to disease,

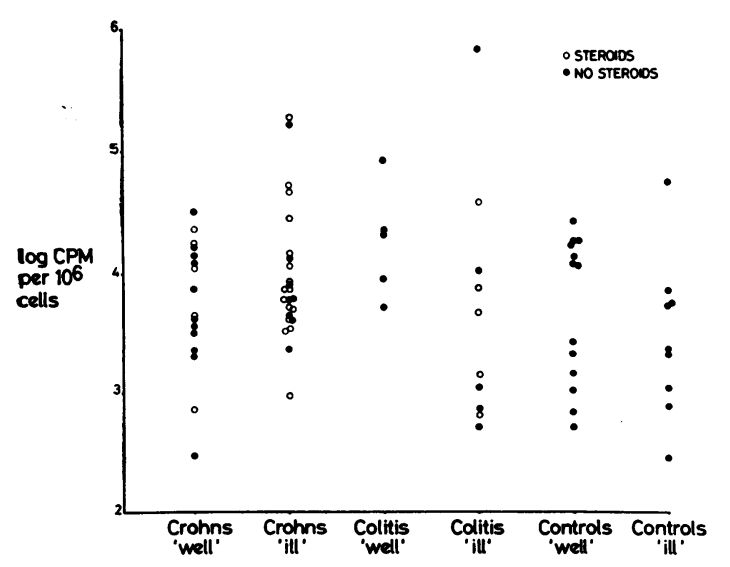

FIG Lymphocyte response to $\mathrm{PHA}$ degree of illness, or steroid therapy was detected. Results are shown in the figure.

In some of the patients early in the series the lymphocyte response to PHA was assessed morphologically by examination of stained smears. The numbers assessed in this way were insufficient for meaningful analysis and these results are omitted from the series.

\section{Mantoux test (table IV)}

The Mantoux reaction showed no significant variation with disease group or degree of illness. Steroids were associated with depression of the reaction in Crohn's patients which was significant $(P<0.04)$ in the 'ill' group. This depressive effect of steroids was not significant in the small group of 'ill' colitis patients, although intensity of response was diminished.

\begin{tabular}{llcl}
\hline Group & & \multicolumn{2}{c}{ Mantoux Test } \\
\hline Crohn's disease & Well & $12 / 19$ & \\
& Steroids & $2 / 5$ & \\
& No steroids & $10 / 14$ & \\
& Ill & $10 / 33$ & \\
& Steroids & $4 / 22^{1}$ & \\
& No steroids & $6 / 11^{1}$ & \\
Colitis & Total & $22 / 52$ & $(42 \%)$ \\
& Well & $4 / 7$ & \\
& III & $5 / 12$ & \\
& Steroids & $3 / 7$ & \\
& No steroids & $2 / 5$ & \\
Control & Total & $9 / 19$ & $(47 \%)$ \\
& Well' & $15 / 22$ & \\
& III" & $15 / 24$ & \\
& Total & $30 / 46$ & $(65 \%)$ \\
\hline
\end{tabular}

Table IV Positive responses to the Mantoux test ${ }^{1} \mathbf{P}<0.04 ;{ }^{2}$ None on steroids 
The response was substantially, but not significantly, diminished in the 'ill' steroid-treated Crohn's patients compared with the 'well' steroid-treated Crohn's patients. This is consistent with the lower median prednisone dosage in the latter group.

\section{$D N C B$ response (table $V$ )}

There was no variation with the type of disease or degree of illness. Steroid treatment was associated with depression of the response in the 'ill' Crohn's patients $(P<0.05)$.

\begin{tabular}{llcl}
\hline Group & & \multicolumn{2}{c}{ DNCB Test } \\
\hline Crohn's disease & Well & $15 / 19$ & \\
& Steroids & $3 / 5$ & \\
& No steroids & $12 / 14$ & \\
& III & $17 / 32$ & \\
& Steroids & $9 / 21^{1}$ & \\
& No steroids & $8 / 11^{1}$ & \\
Colitis & Total & $32 / 51$ & $(63 \%)$ \\
& Well & $4 / 7$ & \\
& III & $10 / 12$ & \\
& Steroids & $4 / 6$ & \\
& No steroids & $6 / 6$ & \\
Control & Total & $14 / 19$ & $(74 \%)$ \\
& Well & $20 / 22$ & \\
& Ill & $14 / 24$ & \\
& Total & $34 / 46$ & $(74 \%)$ \\
\hline
\end{tabular}

Table $\mathrm{V}$ Positive responses to the DNCB test

${ }^{1} \mathrm{P}<0.05 ;{ }^{2}$ None on steroids

\section{SERIAL TESTING}

Serial immune competence tests were carried out in 14 of the 'ill' Crohn's disease patients, in four ulcerative colitis patients, 13 of the 'ill' control group, and 18 of the 'well' control group. Tests were performed at about four weeks after surgical treatment.

There were no consistent significant changes in lymphocyte count or lymphocyte response to PHA in any of the groups after surgical treatment.

Similarly, surgery had no effect on serum IgG levels regardless of disease, degree of illness, or steroid therapy. However, there were striking changes in serum IgA and IgM levels (table VI).

Before surgery IgA values in 'ill' control patients were significantly lower than in 'ill' Crohn's patients $(P<0.02)$. Following surgery, there was a nonsignificant increase in IgA in the control patients, and a significant, consistent decrease in $\operatorname{IgA}$ in the Crohn's group ( $P<0.006)$. These opposing changes in serum IgA following surgery abolished the initial preoperative significant difference between Crohn's and control patients. The difference in behaviour of the serum IgA levels in response to surgery in the two groups of patients is highly significant $(\mathrm{P}<0.006)$.

\begin{tabular}{|c|c|c|c|c|}
\hline \multirow{2}{*}{$\begin{array}{l}\text { Patient } \\
\text { Group }\end{array}$} & \multicolumn{2}{|c|}{$I g A(m g / 100 \mathrm{ml})$} & \multicolumn{2}{|c|}{$\operatorname{IgM}(\mathrm{mg} / 100 \mathrm{ml})$} \\
\hline & Preoperative & Postoperative & Preoperative & Postoperative \\
\hline \multirow{2}{*}{$\begin{array}{l}\text { IIl Crohn's } \\
\text { (13) } \\
\text { Ill control } \\
\text { (14) }\end{array}$} & $365^{1,2}$ & $291^{2,4}$ & $134^{5}$ & $193^{5}$ \\
\hline & $222^{1,3}$ & $260^{3,4}$ & $115^{\circ}$ & $149^{\circ}$ \\
\hline
\end{tabular}

Table VI Changes in serum IgA and IgM with surgery ${ }^{1} \mathrm{P}<0.02,{ }^{2} \mathrm{P}<0.006,{ }^{3}$ not significant, ${ }^{4}$ not significant, ${ }^{5} \mathrm{P}<0.005$ ${ }^{{ }^{P}} \mathbf{P}<0.05$

Both 'ill' Crohn's and 'ill' control groups showed an increase in serum IgM levels following surgery ( $P<0.005$ Crohn's, $P<0.05$ controls).

Considering the Mantoux and DNCB responses, four 'ill' control patients who were DNCB negative preoperatively became positive with improvement in their health following surgery. There was a general tendency to stronger reactions on repeated testing although one weak DNCB-positive response in a 'well' control patient became negative after surgery. In the 'ill' Crohn's patients, DNCB and Mantoux responses fluctuated with the clinical state of the patient and the dosage of steroids. Four patients became DNCB positive with the improvement in their general health following surgery, accompanied by reducing or discontinuing steroids. Three other patients became DNCB negative when ill and on steroids but reverted to positive with remission and stopping of steroids. Similar variations occurred in the Mantoux reaction related to changes in general health and/or steroid dosage.

\section{Discussion}

None of the five parameters tested differed significantly between ulcerative colitis and control patients, regardless of degree of illness or steroid therapy. Thus, according to our data, the immune competence of ulcerative colitis patients is normal.

In the Crohn's patients, lymphocyte counts were similar to those of controls. Our findings differ from those of Strober, Wochner, Carbone, and Waldmann (1967) who demonstrated significant lymphocytopenia in seven patients with Crohn's disease.

Serum IgA levels were elevated in patients with Crohn's disease. This finding has been previously reported (Deodhar, Michener, and Farmer, 1969) and is probably due to increased local IgA production in the bowel wall, either as a non-specific response to the inflammatory process or as a result of greater antigenic access through ulcerated mucosa. The higher levels in the 'ill' Crohn's patients are consistent with either concept. The normal serum IgA 
levels in our colitis patients may be due to the smaller amount of lymphoid tissue in the wall of the large bowel. The fall in serum IgA in 'ill' Crohn's patients following resection is explicable on the basis of removal of areas of $\operatorname{IgA}$ synthesis in the intestinal wall.

The rise in serum IgM after resection has been previously recorded (Gelernt, Present, and Janowitz, 1972). However, contrary to our results, these authors reported that the rise in IgM was maximal at four days and that levels had reverted to normal at four weeks. Their explanation was that there was binding of serum IgM to the diseased bowel, and resection resulted in an increase in circulating IgM. They compared this increase in serum IgM with that seen following removal of an immunologically destroyed transplant. Another explanation is that there may be an interrelationship between levels of circulating IgA and IgM. The rise in serum IgM after surgery would then be secondary to the fall in serum IgA.

The lowest mean levels of $\operatorname{IgG}, \operatorname{IgA}$, and IgM all occurred in the steroid-treated 'well' Crohn's group. This might reflect the quiescent state of the disease or be a chance finding related to the relatively small number of patients in this group.

Lymphocyte responses to PHA were similar in all patient groups in our study. Eleven previous reports of this investigation in the literature are split six to five in favour of diminution of the lymphocyte PHA response (table VII). Intrinsic variation in the same subjects on different days (Sachar, Taub, Brown, Present, Koreltiz, and Janowitz, 1972), and many methodological differences in culture technique and assessment make comparisons and conclusions unsatisfactory. The well controlled study of Ropke (1972), using differing concentrations of PHA, differing culture times, and both autologous and homologous sera, showed no differences between Crohn's and control lymphocytes in their response to PHA.

Depression of the Mantoux response occurred only in the 'ill' steroid-treated Crohn's group. We do not consider that this steroid-treated group differed significantly in clinical state from the non-steroid treated 'ill' Crohn's patients. The major distinction between the two groups was that the non-steroid patients were admitted with acute symptoms early in the course of the illness, while the steroid-treated patients were admitted with exacerbations of a previously diagnosed and treated illness. Nine of the 11 non-steroid treated 'ill' Crohn's patients underwent major abdominal surgery during their initial hospital admission. Thus we believe that the depression of the Mantoux response in the 'ill' steroid-treated Crohn's patients was due to steroid therapy. This depressive effect of steroids on the Mantoux response is well recognized (Carey, Harvey, Howard, and Winkenwerder, 1950; Long and Favour, 1950; Lovell, Goodman, Hudson, Armitage, and Pickering, 1953).

There was no overall impairment of DNCB response in the Crohn's patients, although some depression occurred with steroid treatment in the 'ill' Crohn's group. These results are in agreement with those of Geffroy et al (1971) who demonstrated delayed hypersensitivity reactions to DNCB in 12 out of 13 Crohn's patients. However, they are contrary to those of Jones et al (1969) who reported a positive response to DNCB in only 11 out of 26 patients with Crohn's disease.

Even including the steroid-treated cases of Crohn's disease there were no overall significant differences in the rates of response to DNCB and PPD in Crohn's and control groups in this series. Thus there was no evidence of impairment of the delayed hypersensitivity response in Crohn's disease.

The elevation of serum IgA and its subsequent fall after surgery are likely to be non-specific findings. Similarly, the elevation of serum IgM following resection of involved bowel is probably not directly related to the patient's immune competence.

We have therefore been unable to demonstrate any evidence of diminished immune competence in patients with Crohn's disease. Review of the evidence in this and other series suggests that it is

Authors
Walker and Greaves (1969)
Brown, Taub, Present, and Janowitz (1970)
Parent, Barrett, and Wilson (1971)
McHattie, Magil, Jeejeebbhoy, and Falk (1971)
Geffroy, Colin, Hecketsweiler, and Segrestin (1971)
Sachar, Taub, Brown, Present, Korelitz, and Janowitz (1972)
Aas, Huizenga, Newcomer, and Shorter (1972)
Ropke (1972)
Guillou, Brennan, and Giles (1973)
Cave and Brooke (1973)
Asquith, Kraft, and Rothberg (1973)

Findings

Decreased

Decreased

Decreased

Normal

Decreased

Normal

Normal

Decreased

Decreased

Normal

Table VII Lymphocyte response to PHA in Crohn's disease in previous series 
unjustified to consider that diminished immune competence is an important factor in the pathogenesis of Crohn's disease.

We would like to thank Dr J. Rhodes for allowing us to study patients under his care. Dr J. W. Keyser, Mr G. Ll. Watkins, and Mr A. Morgan of the Department of Medical Biochemistry, Welsh National School of Medicine, at Cardiff Royal Infirmary, were responsible for the immunoglobulin estimations. Mrs Ursula Jones and Mr D. Grimshaw gave technical assistance with the PHA lymphocyte response. Dr Joyce Davidson helped with the delayed hypersensitivity skin testing.

\section{References}

Aas, J., Huizenga, K. A., Newcomer, A. D., and Shorter, R. G. (1972). Inflammatory bowel disease: lymphocytic responses to non-specific stimulation in vitro. Scand. J. Gastroent., 7, 299non-spec.

Aisenberg, A. C. (1962). Studies on delayed hypersensitivity in Hodgkin's disease. J. clin. Invest., 41, 1964-1970.

Asquith, P., Kraft, S. C., and Rothberg, R. M. (1973). Lymphocyte responses to nonspecific mitogens in inflammatory bowel disease. Gastroenterology, 65, 1-7.

Blackburn, G., Hadfield, G., and Hunt, A. H. (1939). Regional ileitis. St. Barts. Hosp. Rep., 72, 181-224.

Brown, S. M., Taub, R. N., Present, D. H., and Janowitz, H. D. (1970). Short-term lymphocyte cultures in regional enteritis. Lancet, 1, 1112.

Carey, R. A., Harvey, A. M., Howard, J. E., and Winkenwerder, W. L. (1950). The effect of adrenocorticotropic hormone (ACTH) and cortisone on the course of chronic bronchial asthma. Bull. Johns. Hopk. Hosp., 87, 387-414.

Cave, D., and Brooke, B. N. (1973). A study of lymphocyte function in Crohn's disease using the mitotic index. Brit. J. Surg., 60, 319.

Coulson, A. S., and Chalmers, D. G. (1964). Separation of viable lymphocytes from human blood. Lancet, 1, 468-469.

Deodhar, S. D., Michener, W. M., and Farmer, R. G. (1969). A study of the immunologic aspects of chronic ulcerative colitis and transmural colitis. Amer. J. clin. Path., 51, 591-597.
Fletcher, J., and Hinton, J. M. (1967). Tuberculin sensitivity in Crohn's disease: a controlled study. Lancet, 2, 753-754.

Geffroy, Y., Colin, R., Hecketsweiler, P. H., and Segrestin, M. (1971). Traitement de la maladie de Crohn par le B.C.G. Arch. Mal. Appar. dig., 60, 299-308.

Gelernt, I. M., Present, D. H., and Janowitz, H. D. (1972). Alterations in serum immunoglobulins after resection for ulcerative and granulomatous disease of the intestine. Gut, 13, 21-23.

Guillou, P. J., Brennan, T. G., and Giles, G. R. (1973). Lymphocyte transformation in the mesenteric lymph nodes of patients with Crohn's disease. Gut, 14, 20-24.

Hinz, C. F., Jr., Perlmann, P., and Hammarström, S. (1967). Reactivity in vitro of lymphocytes from patients with ulcerative colitis. J. Lab. clin. Med., 70, 752-759.

Jones, J. V., Housley, J., Ashurst, P. M., and Hawkins, C. F. (1969). Development of delayed hypersensitivity to dinitrochlorobenzene in patients with Crohn's disease. Gut, 10, 52-56.

Long, J. B., and Favour, C. B. (1950). The ability of ACTH and cortisone to alter delayed type bacterial hypersensitivity. Bull. Johns Hopk. Hosp., 87, 186-202.

Lovell, R. R. H., Goodman, H. C., Hudson, B., Armitage, P., and Pickering, G. W. (1953). The effects of cortisone and adrenocorticotrophic hormone on experimental inflammations in the human skin. Clin. Sci., 12, 41-55.

Mancini, G.. Carbonara, A. O., and Heremans, J. F. (1965). Immunochemical quantitation of antigens by single radial immunodiffusion. Immunochemistry, 2, 235-254.

McHattie, J., Magil, A., Jeejeebbhoy, K., and Falk, R. E. (1971). Immunoresponsiveness of lymphocytes from patients with regional ileocolitis (Crohn's disease) by in vitro testing. Clin. Res., 19, 779.

Parent, K., Barrett, J., and Wilson, I. D. (1971). Investigation of the pathogenic mechanisms in regional enteritis with in vitro lymphocyte cultures. Gastroenterology, 61, 431-439.

Phear, D. N. (1958). The relation between regional ileitis and sarcoidosis. Lancet, 2, 1250-1251.

Ropke, C. (1972). Lymphocyte transformation and delayed hypersensitivity in Crohn's disease. Scand. J. Gastroent., 7, 671-677.

Sachar, D. B., Taub, R. N., Brown, S. M., Present, D. H., Korelitz, B. 1., and Janowitz, H. D. (1972). Iymphocyte responsiveness in inflammatory bowel disease. Gastroenterology, 62, 804.

Strober, W., Wochner, R. D., Carbone, P. P., and Waldmann, T. A. (1967). Intestinal lymphangiectasia: a protein-losing enteropathy with hypogammaglobulinemia, lymphocytopenia and impaired homograft rejection. J. clin. Invest., 46, 1643-1656.

Walker, J. G., and Greaves, M. F. (1969). Delayed hypersensitivity and lymphocyte transformation in Crohn's disease and proctocolitis. (Abstr.) Gut, 10, 414.

Williams, W. J. (1965). A study of Crohn's syndrome using tissue extracts and the Kveim and Mantoux tests. Gut, 6, 503-505. 